\title{
Jan Zimmermann
}

Uniwersytet Jagielloński

jan.zimmermann@uj.edu.pl

ORCID 0000-0003-0268-1746

https://doi.org/10.26881/gsp.2020.2.09

\section{Czy schyłek odwołania administracyjnego?}

1. Sześćdziesięciolecie obowiązywania kodeksu postępowania administracyjnego jest m.in. okazją do przyjrzenia się tym jego podstawowym instytucjom, które nie tylko przetrwały próbę czasu, ale w nowej rzeczywistości demokratycznego państwa prawnego nabrały jeszcze większego znaczenia. Jedną z nich jest odwołanie administracyjne. W demokratycznym państwie prawnym cały system prawa, nie tylko system prawa administracyjnego, musi się opierać o zasadę, według której obywatel, do którego jest skierowana norma prawna, ma prawo ją zakwestionować. W takim państwie bowiem obywatel powinien być chroniony przed nadmierną jego ingerencją. Oczywiście, jeśli jest to norma generalna, a zwłaszcza powszechnie obowiązująca, środki służące do jej zakwestionowania są dla jednostki w istocie bardzo ograniczone albo praktycznie niemal abstrakcyjne. Jeśli jednak jest to norma indywidualna, skierowana do konkretnej osoby i wyznaczająca wprost uprawnienia lub obowiązki tej właśnie osoby, środki tego rodzaju powinny być mocne, konkretne i ustanowione przez akty najwyższego rzędu.

Obowiązująca Konstytucja spełnia ten wymóg w rozdziale zatytułowanym „Wolności, prawa i obowiązki człowieka i obywatela”, stanowiąc w jego części „Środki ochrony wolności i praw” m.in.: „Każda ze stron ma prawo do zaskarżenia orzeczeń i decyzji wydanych w pierwszej instancji. Wyjątki od tej zasady oraz tryb zaskarżania określa ustawa" (art. 78). Z aksjologicznego punktu widzenia ustanowienie w Konstytucji takiej normy nawiązuje do podstawowych wartości, które mają w państwie demokratycznym znaczenie nadrzędne, takich jak sprawiedliwość społeczna czy uszanowanie praw obywatelskich. Z prawnego punktu widzenia norma ta jest fundamentem dla prawa podmiotowego - w zakresie prawa administracyjnego - fundamentem odrębnego publicznego prawa podmiotowego. Taka konstatacja jest zupełnie wystarczająca dla oparcia na niej twierdzenia, że odwołanie administracyjne, będące podstawowym środkiem zaskarżania decyzji administracyjnych, znajduje swoją niezaprzeczalną podstawę w obowiązującej Konstytucji i jest przez nią w pełni legitymizowane. Jednakże twierdzenie o zasadniczym znaczeniu odwołania administracyjnego można wyprowadzać również bez nawiązywania de lege lata do obowiązujących unormowań konstytucyjnych. Jego uzasadnienie wynika równie dobrze z genezy prawa administracyjnego 
i postępowania administracyjnego oraz z aksjologicznych założeń tego postępowania'. Otóż prawo administracyjne jest tą gałęzią prawa, która w zasadniczej swojej części reguluje stosunki między państwem a obywatelem, istniejące w różnych dziedzinach życia i na różnych płaszczyznach. Prawo administracyjne jest więc zbudowane na założeniu nierówności między podmiotami stosunku prawnego, w którym jeden podmiot (najczęściej organ administracji publicznej) ma swoistą przewagę nad podmiotem drugim (jednostką, obywatelem), wobec którego dysponuje przydzieloną mu częścią władztwa państwowego. Ta oczywista prawda musiała spowodować powstanie konstrukcji prawnych, przy pomocy których podmiot słabszy mógłby się skutecznie bronić przed działaniami podmiotu silniejszego. Dlatego też pojawiła się instytucja rekursu hierarchicznego, która następnie przerodziła się w odwołanie administracyjne i została obudowana wieloma instytucjami procesowymi, dodatkowo (obok rekursu) chroniącymi obywatela. Nie trzeba więc specjalnie dowodzić, że i genetycznie, i aksjologicznie odwołanie administracyjne jest istotą postępowania administracyjnego, co więcej - jest ono istotą stosunków: państwo - obywatel. Wymyślono je po to, aby złagodzić nierówność tych stosunków. Ponieważ prawo administracyjne ze swojej istoty powoduje i zawsze będzie powodować taką nierówność, to odwołanie jest i zawsze będzie instrumentem nieodzownym dla jej łagodzenia. Wprawdzie poszczególne ustawodawstwa poszukują także innych rozwiązań służących temu łagodzeniu (mediacja, umowa lub ugoda administracyjna itd.), to jednak nie ma żadnych przesłanek, żeby twierdzić, że odwołanie administracyjne się przeżyło, czy też że jego znaczenie słabnie. Instytucja ta, należąc do istoty prawa administracyjnego i do kanonów postępowania administracyjnego, musi trwać. Jej ewentualne zniszczenie uczyni cały system tej gałęzi prawa niedemokratycznym, zakłóci wartości leżące u jej podstaw i zupełnie zmieni proporcje wewnątrz systemu prawa.

2. Wbrew powyższym, oczywistym stwierdzeniom, pojawiają się jednak w ostatnim czasie zapatrywania lub unormowania, które zmierzają może nie do zniszczenia instytucji odwołania administracyjnego, ale w każdym razie do zmniejszenia jego roli albo do dewaluacji procesowej tego środka prawnego. Niepokoją one zarówno z punktu widzenia teorii postępowania administracyjnego, jak i z punktu widzenia idei państwa prawnego i idei swobód oraz praw obywatelskich, a także z punktu widzenia aksjologicznego. Dano temu wyraz w jednym z najnowszych, kompleksowych opracowań dotyczących odwołania administracyjnego, pisząc, że opracowanie to „jest głosem w obronie odwołania jako instytucji prawnej o fundamentalnym znaczeniu dla postępowania administracyjnego i pozycji prawnej jednostki w tym postępowaniu"2. Wyrażono tu pogląd, że „odwołanie w ogólnym postępowaniu administracyjnym jest prawniczym osiągnięciem cywilizacyjnym służącym ochronie jednostki, jest instytucją konieczną i - przy aktualnym modelu sądownictwa administracyjnego - niemożliwą

1 O wartościach kształtujących prawo odwołania pisze obszernie B. Adamiak [w:] eadem, System Prawa Administracyjnego Procesowego, t. 2, Weryfikacja rozstrzygnięć w postępowaniu administracyjnym ogólnym, red. eadem, Warszawa 2019, s. 71 i n.

2 M. Bąkowski, M. Bogusz [w:] Postępowanie odwoławcze w ogólnym postępowaniu administracyjnym, t. 1, red. M. Bogusz, Gdańsk 2019, s. 11. 
do zastąpienia innymi środkami prawnymi". Całkowicie i mocno podzielam to zapatrywanie. Celem niniejszego opracowania jest pokazanie i pewne uporządkowanie tych widocznych tendencji, a w konsekwencji wskazanie na niebezpieczeństwa, jakie one ze sobą niosą.

3. Pierwszy element, jaki można tu dostrzec, dotyczy wskazanej wyżej regulacji konstytucyjnej. Prawidłowa, moim zdaniem, interpretacja cytowanego art. 78 Konstytucji oznacza przede wszystkim to, że zawarte w nim słowo „zaskarżenie” zawiera w sobie dwa elementy: element zakwestionowania decyzji pierwszej instancji i jednocześnie element poddania się orzeczeniu organu drugiej instancji, który w momencie wniesienia odwołania staje się właściwy do załatwienia sprawy administracyjnej ${ }^{3}$. Elementy te oznaczają, że regulacja konstytucyjna wymusza jako zasadę merytoryczne orzeczenie organu drugiej instancji, zostawiając możliwość orzeczenia kasacyjnego w sferze wyjątku. Analizowany przepis posługuje się również słowami „w pierwszej instancji”, co oznacza konieczność zorganizowania dwóch instancji zamiast jednej. Oznacza to, że próby całkowitego lub szerszego niż dotąd zastąpienia odwołania wnioskiem o ponowne rozpatrzenie sprawy należy uznać za niekonstytucyjne.

Powyższe zapatrywanie ${ }^{4}$ jest jednak podważane $w$ literaturze, przez co regulacja art. 78 Konstytucji RP jest dezawuowana ${ }^{5}$. Argumentacja podawana przez przeciwników tej interpretacji cytowanego przepisu nie jest jednak przekonująca z kilku powodów. Po pierwsze, sięga ona do porównań dyskutowanego uregulowania z jego odpowiednikiem zawartym w Konstytucji tzw. marcowej, czego nie uzasadnia upływ 76 lat i zupełnie inne realia prawne, w jakich Konstytucja z 1921 r. funkcjonowała. Po drugie, błędne jest zestawianie art. $78 \mathrm{z}$ art. 176 ust. 1 Konstytucji RP, ustalającym, że postępowanie sądowe jest co najmniej dwuinstancyjne. Nie można na tej podstawie stwierdzać (wykracza to zdecydowanie poza granice wykładni systemowej), że skoro ustawodawca konstytucyjny wypowiedział się wyraźnie i dosłownie w kwestii dwuinstancyjności postępowania sądowoadministracyjnego, a nie zrobił tego tak wyraźnie wobec postępowania administracyjnego, to tym samym nie wprowadził do Konstytucji zasady dwuinstancyjności postępowania administracyjnego, czyli nie stworzył konstytucyjnej bazy dla odwołania. Po trzecie, nieprawidłowe jest traktowanie zawartości art. 78 Konstytucji jako „zasady ustrojowej”. Nie jest przecież kwestią ustrojową określanie zagadnienia przejścia sprawy administracyjnej z jednej do drugiej instancji, a taka

3 O interpretacji art. 78 Konstytucji RP jednoznacznie wyznaczającej administracyjny tok instancji: ibidem, s. 20-21. Por. też B. Adamiak, Konstytucyjna zasada dwuinstancyjności postępowania administracyjnego [w:] Pozycja samorzqdowych kolegiów odwoławczych w postępowaniu administracyjnym, red. C. Martysz, E. Matan, Kraków 2005, s. 26 oraz eadem, Zasada dwuinstancyjności postępowania administracyjnego w świetle zmian struktury organizacyjnej organów administracji publicznej. Miejsce zasady dwuinstancyjności w systemie gwarancji praw jednostki [w:] Jednostka wobec działań administracji publicznej, red. E Ura, E. Feret, S. Pieprzny, Rzeszów 2016, s. 375 oraz J. Zimmermann, Kilka refleksji o nowelizacji kodeksu postępowania administracyjnego, PiP 2017, z. 8, s. 13.

4 W pełni popierane przez B. Adamiak [w:] eadem, Weryfikacja rozstrzygnięć w toku instancji [w:] System Prawa Administracyjnego, t. 9, Prawo procesowe administracyjne, red. R. Hauser. Z. Niewiadomski, A. Wróbel, Warszawa 2010, s. 202-204.

5 Z. Kmieciak, Zarys teorii postępowania administracyjnego, Warszawa 2014, s. 309. 
jest treść spornego przepisu. Jest to przepis materialny a jego ustrojowym odbiciem byłoby określanie organów mających być drugą instancją administracyjną. Kto inny trafnie zresztą zauważył, że „rekonstrukcja rozumienia pojęcia »pierwsza instancja« nie może zostać sprowadzona do znaczenia, jakie przypisują mu ustawy regulujące ustrój (...) władzy publicznej"6.

Przedstawiona tu kontrowersja pokazuje, że już na etapie analizy unormowań konstytucyjnych pojawiają się głosy zmierzające do pomniejszenia instytucji odwołania administracyjnego. Mogą one spowodować to niebezpieczeństwo, że w dyskusji o randze odwołania administracyjnego będziemy pozbawieni konstytucyjnego oparcia dla tej instytucji, co od razu znacznie osłabi jej rangę.

4. Podobne stanowiska można również znaleźć w oderwaniu od unormowań konstytucyjnych. Na płaszczyźnie teoretycznej należy tu wskazać na zapatrywania widzące w administracyjnym toku instancji jedynie walor procesowy i traktujące odwołanie administracyjne tylko jako środek uruchamiający kontrolę instancyjną. Już Emanuel Iserzon twierdził, że „celem postępowania odwoławczego (...) jest zarówno ocena, czy odwołanie strony jest uzasadnione, jaki i sprawdzenie, czy decyzja jest prawidłowa"7. Oczywiście takie sformułowanie jest prawdziwe i trudno się w nim dopatrywać błędu, jednak stawia ono pewien znak równości między merytorycznym a kontrolnym celem odwołania a nawet cel merytoryczny nieco osłabia, używając zwrotu: „ocena, czy odwołanie jest uzasadnione". Oczywiście, jeżeli odwołanie jest uzasadnione, to otwiera drogę do wydania przez organ drugiej instancji decyzji merytorycznej, ale organ drugiej instancji wyda taką decyzję nie tylko z tego powodu, ale dlatego, że sam w swoim postępowaniu doszedł do konkluzji różniącej się od rozstrzygnięcia organu pierwszej instancji. Dlatego widzę w zdaniu E. Iserzona pewne zachwianie równości między obydwoma celami odwołania, co oczywiście jeszcze samego odwołania nie sprowadza jedynie do roli środka inspirującego kontrolę. Jeżeli jednak pójdzie się dalej tym tropem, to można dojść do wniosku, że istotą odwołania administracyjnego jest tylko „żądanie oceny prawidłowości zaskarżonej decyzji, nie zaś żądanie ponownego rozpatrzenia sprawy administracyjnej”, i że „dopiero w ramach uprawnień kontrolnych organ odwoławczy może podejmować zarówno decyzje uchylające zaskarżoną decyzją (...) jak i decyzje kasacyjne" ${ }^{\prime 8}$. Wydaje się, że tego rodzaju tezy są sprzeczne nie tylko z ideą instancyjności administracyjnej, ale także z uregulowaniami k.p.a., z których wynika niezbicie, że z chwilą wniesienia odwołania przed organ drugiej instancji przenosi się sprawa administracyjna, a organem właściwym do jej rozpatrzenia staje się właśnie ten organ. Skoro nabywa on kompetencje do jej rozpatrzenia i załatwienia, to załatwienie to powinno polegać na tym samym, na czym może polegać załatwienie

6 M. Wyrzykowski, M. Ziółkowski, Konstytucyjny status proceduralny jednostki jako adresata działań organów administracji [w:] System Prawa Administracyjnego, t. 2, Konstytucyjne podstawy funkcjonowania administracji publicznej, red. R. Hauser, Z. Niewiadomski, A. Wróbel, Warszawa 2012, s. 288.

7 E. Iserzon [w:] idem, J. Starościak, Kodeks postępowania administracyjnego. Komentarz, teksty, wzory i formularze, Warszawa 1970, s. 235.

8 A. Wróbel [w:] idem, M. Jaśkowska, Kodeks postępowania administracyjnego. Komentarz, Kraków 2000, s. 734. 
tejże sprawy przez organ pierwszej instancji. Przeniesienie sprawy oznacza, że decyzja instancji pierwszej upada a zastąpi ją decyzja instancji drugiej. Użyte przez kodeks określenia: „uchyla” lub „utrzymuje w mocy” stanowią tylko skróty myślowe, które w rozwiniętej formie znaczą tyle, co „pozbawia decyzję mocy obowiązującej, gdyż jego konkluzja jest odmienna" i „nie pozbawia jej mocy obowiązującej, gdyż jego konkluzja jest identyczna”.,Utrzymanie w mocy" nie oznacza więc odrodzenia się decyzji organu pierwszej instancji, ale wydanie decyzji nowej o takiej samej treści. Wchodzi tu zresztą w grę zasada bezwzględnego wiązania norm prawa administracyjnego, jak i często niedostrzegana zasada aktualności, która zobowiązuje organ drugiej instancji do decydowania według stanu faktycznego i prawnego istniejącego w dacie wydawania decyzji przez niego właśnie. W sumie można powiedzieć, że administracyjny tok instancji ma charakter w istocie materialny, a procesowa jest tylko jego normatywna obudowa. Jednak nawet zaliczanie odwołania do tejże obudowy nie pozwala na zaprzeczenie jego roli materialnej, skoro wyzwala merytoryczną (materialną właśnie) aktywność organu drugiej instancji. Tak samo zresztą każdy wniosek o wszczęcie postępowania administracyjnego, wniesiony przez stronę, nie uruchamia tylko czynności procesowych, ale zmierza do rozstrzygnięcia materialnego, sprzężonego z materialnym (opartym przecież na prawie materialnym) interesem prawnym, będącym legitymacją tej strony do skutecznego wniesienia podania o zastosowanie prawa materialnego.

Oczywiście polemizując z przytoczonym poglądem, nie dezawuuję kontrolnego celu odwołania administracyjnego, który zresztą w niektórych unormowaniach kodeksu wysuwa się na pierwszy plan. Tak jest np. w przypadku regulacji dotyczącej zasady zakazu reformationis in peius (art. 139). Jednak uważam, że przypisywanie odwołaniu i działaniu organu drugiej instancji wyłącznie celu kontrolnego wypacza ideę odwołania administracyjnego i przyczynia się od strony teoretycznej do powstawania innych niepokojących prób ograniczania instytucji odwołania, o jakich mowa w tym opracowaniu.

5. Kolejnym kierunkiem zapatrywań zmierzających do osłabienia roli odwołania administracyjnego jest zestawianie administracyjnego toku instancji z kontrolą sądowoadministracyjną. Zanim powiem o szczegółach w tym zakresie, chcę zwrócić uwagę na pewne nieporozumienie tkwiące u źródła tego problemu. Otóż moim zdaniem, nie można porównywać tych dwóch instytucji, jednakowo w systemie merytorycznego sądownictwa administracyjnego i w systemie kontrolnym tego sądownictwa. W systemie merytorycznym, w którym sąd administracyjny jest władny do rozstrzygnięcia sprawy administracyjnej, czyli do zastąpienia w tym zakresie organu administracji publicznej, istnienie instytucji odwołania można uznać za problematyczne lub nawet zbędne. Tu bowiem rzeczywiście mogłoby dojść do spiętrzenia nawet czterech instancji, w jakich sprawa administracyjna byłaby rozpatrywana. W tych systemach jest zatem słuszne ograniczanie odwołania albo budowanie konstrukcji alternatywnych, zakładających możliwość wyboru środka prawnego służącego od decyzji administracyjnej między odwołaniem a skargą sądową. Tam jednak, gdzie mamy do czynienia z kontrolnym systemem sądownictwa administracyjnego, w którym - tak jak w Polsce - sąd administracyjny tylko bada zgodność z prawem zaskarżanych do niego aktów, 
obie możliwości zaskarżenia decyzji są w sposób oczywisty sobie nierówne. Wnosząc odwołanie, można bowiem osiągnąć nową decyzję administracyjną, która będzie wydana przy spełnieniu wszelkich zasad procesowych. Wnosząc skargę do sądu, można osiągnąć jedynie uchylenie wydanej decyzji, i to tylko z powodu jej niezgodności z prawem, bez względu na wszelkie inne okoliczności. Taki obraz rzeczy przekonuje, moim zdaniem, że ograniczanie odwołania administracyjnego z tego powodu, że przecież istnieje sądownictwo administracyjne, jest w naszym systemie i błędne, i niebezpieczne dla obywatela.

Tymczasem w najnowszej literaturze pojawiają się takie właśnie zapatrywania. Na podstawie analizy rozwiązań wielu państw twierdzi się na przykład, że „tryb odwołania administracyjnego traktowany jest współcześnie jako rodzaj procedury wstępnej, uruchomienie której jest konieczne dla wniesienia skargi sądowej" . Nie przeczę, że Autor przeprowadził w tej sprawie dokładną analizę prowadzącą do wniosku, że w wielu systemach skarga do sądu administracyjnego powinna być poprzedzona odwołaniem, a postępowanie odwoławcze ma poprzedzać postępowanie sądowe. Tyle tylko, że nie można na tej podstawie wyprowadzać generalnej tezy, że w takiej sytuacji postępowanie odwoławcze ma być uznawane za „procedurę wstępną”. Jest to stwierdzenie idące o wiele za daleko. W opisanych sytuacjach postępowanie odwoławcze ma swój cel do spełnienia (cel merytoryczny), a postępowanie sądowe - swój (cel kontrolny zawężony do kryterium zgodności z prawem). Nie trzeba tłumaczyć, że cele te różnią się od siebie, toteż sekwencja procedur nie jest tu motywowana merytorycznie. System odwoławczy w Polsce nie jest alternatywą dla postępowania sądowego, a jedynie może je poprzedzać.

6. Skoro postępowanie odwoławcze zmierza w zasadzie do wydania decyzji merytorycznej i w związku z tym ma formalnie przebiegać tak samo jak postępowanie toczące się w pierwszej instancji, niedopuszczalne wydaje się traktowanie instancyjności administracyjnej jako niepotrzebnej, czy nawet przeszkadzającej w ekonomicznym i sprawnym prowadzeniu postępowania administracyjnego, a traktowanie odwołania jako środka mogącego wręcz hamować tę szybkość i blokować sprawność działania organu. Poglądy zmierzające w tym kierunku są kolejną przyczyną dezawuowania odwołania administracyjnego i wyraźnego obniżania jego rangi kosztem uprawnień obywatela. Znamienne jest zdanie, że „ochrona zasady dwuinstancyjności postępowania administracyjnego nie może być preferowana kosztem innych wartości procesowych, w tym wymagań szybkości i prostoty postępowania"10. Mamy tu do czynienia z nieporozumieniem wynikającym z odrywania od siebie procesowego i merytorycznego znaczenia odwołania administracyjnego, a także z błędnego podejścia aksjologicznego do instytucji administracyjnego toku instancji. Rozpatrując pierwszy z tych dwóch elementów, należy spojrzeć na pryncypia rządzące postępowaniem administracyjnym, którego celem zasadniczym jest osiągnięcie decyzji administracyjnej, czyli rozstrzygnięcie sprawy administracyjnej. Na tym się zasadza materialny (merytoryczny)

9 Z. Kmieciak, Zarys teorii..., s. 283.

10 Ibidem, s. 383. 
sens postępowania. Ma ono oczywiście także swój sens czysto procesowy, ale nakładający się na cel podstawowy. Tych elementów - celów nie można od siebie odrywać, gdyż m.in. podstawową cechą prawa administracyjnego jest szczególnie ścisłe powiązanie ze sobą norm prawa materialnego i norm prawa procesowego. Ta właśnie jedność stanowi istotę prawnych podstaw wszelkiego administrowania. Dlatego też nie można odwołania administracyjnego traktować osobno jako instrumentu służącemu załatwieniu sprawy administracyjnej w drugiej instancji i osobno jako instrumentu jedynie wszczynającego postępowanie przed organem drugiej instancji albo - co gorsza - nie można traktować odwołania wyłącznie jako elementu procesowego. Łączy się to z drugim ze wskazanych elementów - z kwestią aksjologiczną. Otóż, wskazana tu dwoistość postępowania administracyjnego (w tym dwoistość postępowania odwoławczego) przekłada się na pewien podział wartości, jakie tu występują. Zbudowanie zasady dwuinstancyjności i służącej jej instytucji odwołania preferuje wartość, jaką jest ochrona obywatela-strony przed nieprawidłowym rozstrzygnięciem sprawy administracyjnej. Jest to niewątpliwie wartość materialna. W warstwie procesowej występują inne wartości - takie, jak np. szybkość, prostota i upraszczanie działania organu administracyjnego, choć Autor powyższej wypowiedzi - moim zdaniem błędnie - jedne i drugie nazywa wartościami procesowymi. Normy postępowania mają charakter instrumentalny wobec norm procesowych, toteż symetrycznie wartości procesowe powinny ustępować wartościom materialnym. W rezultacie nie chodzi tu akurat o preferowanie wartości materialnych wobec procesowych, ale o to, że z zasady mają one treść istotniejszą niż wartości instrumentalne. Nasuwa się wniosek, że przyspieszanie lub upraszczanie postępowania administracyjnego nie może się odbywać kosztem podstawowych wartości tego postępowania i wynikających z nich zasad ochrony obywatela-strony. W szczególności nie można poświęcać odwołania administracyjnego dla osiągnięcia takich celów, a także dla celów ekonomicznych lub innych celów pozaprawnych. Nie jest to bynajmniej jakikolwiek stan wyższej konieczności, w którym należałoby poświęcić pewne dobro dla ratowania innego dobra większej wartości. Szybkość i prostota postępowania jest oczywiście dobrem, ale dobrem procesowym i większej wartości od tamtego mieć nie może.

7. Jedną z istotnych cech każdego toku instancji, w tym postępowania odwoławczego, a jednocześnie istotnym celem samego odwołania jest to, żeby sprawa administracyjna, przenoszona do kompetencji organu drugiej instancji, była rozpatrywana przez inny organ. Jak się wydaje, zasada dewolutywności odwołania pozwala najlepiej chronić tę wartość, jaką jest obiektywizm oceny i obiektywizm wymagany przy wydawaniu decyzji administracyjnej. Wydanie decyzji po raz drugi przez ten sam organ czy nawet przez organ usytuowany w poziomie, przeczy tej wartości i od razu nasuwa różnego rodzaju podejrzenia o - mówiąc eufemistycznie - nierzetelność lub nieuczciwość wydawanej decyzji. Dlatego wszelkie formy spłaszczania administracyjnego toku instancji, wprowadzane zwłaszcza poprzez instytucję wniosku o ponowne rozpatrzenie sprawy, powinny mieć charakter zupełnie wyjątkowy tym bardziej, że jak była o tym mowa wyżej, można im zarzucić niekonstytucyjność. Można najwyżej przyjąć, że mogą być one wymuszane przez normy ustrojowe, nieznajdujące organu szczebla wyższego 
nad organem wydającym decyzję, a także ewentualnie przez argument racjonalnego spojrzenia. W tej sytuacji rezygnacja z dewolutywności odwołania, poza sytuacjami koniecznymi, jawi się jako kolejny pomysł zmniejszający rangę tego środka prawnego, pozbawiający go jednej z podstawowych cech ${ }^{11}$. Nieco łagodząc to kategoryczne stwierdzenie, da się najwyżej przyjąć, że w istocie odwołania administracyjnego nie leży dosłowna jego dewolutywność (dewolutywność ustrojowo-organizacyjna), ale przynajmniej potrzeba działania w drugiej instancji innego organu niż ten, który decyzję wydał (tzw. dewolutywność personalna) ${ }^{12}$.

W tym kontekście trzeba negatywnie ocenić dążenia do szerszego niż dotąd albo i zupełnego zastąpienia odwołania administracyjnego wnioskiem o ponowne rozpatrzenie sprawy, który pierwotnie był umotywowany tylko względami ustrojowymi. Jednak, jak trafnie zaznaczono w literaturze, założenia tego wniosku „wydają się dziś stanowić wypadkową różnych czynników, pośród których względy ustrojowe są tylko częścią z nich (...) - liczne przykłady dowiodły, że ustawodawca traktuje decyzję o powierzeniu kompetencji do rozpatrzenia środka zaskarżenia jako dowolną, nierzadko kierując się względami partykularnymi"13. Wniosek o ponowne rozpatrzenie sprawy nie spełnia nawet wspomnianego wyżej, kompromisowego postulatu dewolutywności personalnej, a jego preferowanie może się przyczynić do kolejnego nieporozumienia aksjologicznego, o jakim była już mowa: do zrównania wartości procesowych, polegających na upraszczaniu i przyspieszaniu postępowania z wartościami materialnymi, tkwiącymi w istocie administracyjnego toku instancji. Nie wystarcza tu dbałość o to, żeby decyzję odwoławczą wydawał inny pracownik danego organu, gdyż „oczywiste jest, że pracownicy organu pozostają w służbowej zależności, a przy tym tworzą wspólnie korporację urzędniczą"14. Popieranie instytucji wniosku o ponowne rozpatrzenie sprawy nie powinno również bazować na argumentacji wywodzącej się z zasady samodzielności i niezależności jednostek samorządu terytorialnego. Ta szlachetna i ważna skądinąd zasada nie może sięgać do sfery jurysdykcji administracyjnej, w ramach której stosowane jest bezwzględnie obowiązujące prawo materialne. Jeżeli organ gminy lub powiatu wydaje decyzję administracyjną, czyniąc to nawet w zakresie zadań własnych, to po prostu stosuje prawo, a nie wyraża w ten sposób

11 Zastrzeżenia wobec rezygnacji z dewolutywności odwołania zgłasza B. Adamiak [w:] eadem, Weryfikacja rozstrzygnięć w toku... [w:] System Prawa..., s. 213, a także eadem, System Prawa Administracyjnego, t. 2, Weryfikacja rozstrzygnięć w postępowaniu..., s. 150. W innym miejscu tej pracy Autorka ta stwierdza, że „dewolutywność prawa odwołania należy do konstytutywnych elementów tego prawa”, ibidem, s. 141.

12 Por. Z. Kmieciak: Odwołania w postępowaniu administracyjnym, Warszawa 2011, s. 45.

13 P. Dąbrowski: Niedewolutywność środka zaskarżenia w postępowaniu administracyjnym a motywy aktualnego ustawodawcy [w:] Jakość prawa administracyjnego, red. D.R. Kijowski, A. Suławko-Karetko, Warszawa 2012, s. 630-631.

$14 \mathrm{M}$. Oleś, Aksjologia administracyjnego toku instancji jako instrumentu ochrony podmiotu administrowanego w zetknięciu z jurysdykcyjnym działaniem organu administracji publicznej [w:] Aksjologia prawa administracyjnego, red. J. Zimmermann, Warszawa 2017, s. 1022. Por. także P. Dą̧browski, Granice prawa do odwołania administracyjnego w świetle Konstytucji RP [w:] Samorzqdowe kolegia odwoławcze - przeszłość i przyszłość, red. K. Sieniawska, Kraków 2011, s. 163; idem, Niedewolutywność ́́rodka zaskarżenia w postępowaniu administracyjnym a motywy aktualnego ustawodawcy [w:] Jakość prawa..., s. 611 i n. 
swojej samodzielności lub niezależności. Te dwie sfery się ze sobą mijają: samodzielność i niezależność nie wynika z jakiejś specjalnej swobody przy wydawaniu decyzji administracyjnych i odwrotnie: ewentualne luzy decyzyjne nie są wyznaczane przez rozmiar samodzielności lub niezależności organu. W konsekwencji pozbawione jest sensu wymaganie, żeby ograniczać dewolutywność odwołania dlatego, że narusza ona samodzielność lub niezależność. Na marginesie warto zauważyć, że m.in. na takim założeniu zasadzała się koncepcja stworzenia samorządowych kolegiów odwoławczych. Powstały one także dlatego, żeby z jednej strony w sprawach własnych samorządu terytorialnego nie angażować w toku instancji organów administracji rządowej, ale z drugiej strony, właśnie dlatego, żeby tok instancji nie zostawał w danej jednostce samorządowej.

8. Jak już była o tym mowa, mechanizm administracyjnego toku instancji ustalony w kodeksie postępowania administracyjnego polega na wprowadzeniu odpowiednich proporcji między merytorycznymi i kasacyjnymi działaniami organu drugiej instancji, czyli między merytorycznym a kontrolnym celem odwołania administracyjnego. Obydwa cele są tu istotne, ale ustawodawca słusznie preferuje cel merytoryczny, który jest sensem i największą wartością odwołania. Wartość tę deprecjonują twierdzenia dążące do zwiększenia roli decyzji kasacyjnych organu drugiej instancji, które dążą tym samym do uwypuklenia kontrolnego charakteru postępowania odwoławczego. Odwrócenie obowiązującej zasady merytorycznego orzekania w drugiej instancji, albo nawet jej zanegowanie ${ }^{15}$, może prowadzić do złamania istoty zaskarżalności decyzji administracyjnych, i sądzę, że może być tym samym uznane za sprzeczne z Konstytucją.

9. Dotychczas przedstawione postulaty osłabiające rolę i rangę odwołania administracyjnego mają charakter doktrynalny i teoretyczny. Są one ostatnio dość często wyrażane w niektórych pracach dotyczących tych zagadnień. W większości nie zgadzam się z tymi poglądami, jednak można z nimi polemizować, posługując się właśnie argumentami teoretycznymi i doktrynalnymi. Zagadnienie to jednak staje się trudniejsze, jeśli się zauważy, że aktualne rozwiązania prawne również zmierzają do takiego właśnie celu. W takim wypadku nie chodzi tylko o spory akademickie: chodzi o żywe prawo, które w wielu przypadkach szkodzi w sposób oczywisty tej absolutnie podstawowej idei postępowania administracyjnego, jaką jest istnienie odwołania administracyjnego.

Pierwszą regulacją, z którą nie sposób się zgodzić, jest wprowadzona nowelizacją k.p.a. w 2017 r. ${ }^{16}$ możliwość zrzeczenia się odwołania. Kwestii tej poświęcono już wiele miejsca w literaturze, pojawiły się głosy aprobujące ${ }^{17} \mathrm{i}$ krytykujące ${ }^{18}$ tę instytucję. Rzecz

15 Por. W. Chróścielewski, Kasacyjny czy reformacyjny model administracyjnego postępowania odwoławczego?, PiP 2015, z. 1, s. 3 i n.

16 Ustawa z dnia 7 kwietnia 2017 r. o zmianie ustawy - Kodeks postępowania administracyjnego oraz niektórych innych aktów (Dz. U. z 2017 r., poz. 935).

17 M. Masternak-Kubiak, Zrzeczenie się prawa do odwołania w postępowaniu administracyjnym [w:] Jednostka wobec władczej ingerencji organów administracji publicznej. Księga Jubileuszowa dedykowana Profesor Barbarze Adamiak, red. J. Korczak, K. Sobieralski, Wrocław 2019, s. 335 i n.

18 Zwłaszcza praca W. Jakimowicza, O normatywnej konstrukcji zrzeczenia się prawa do wniesienia odwołania od decyzji administracyjnej, „Przegląd Prawa Publicznego” 2018, nr 9, bardzo głęboko wchodząca w istotę zagadnienia. Por. też B. Adamiak [w:] System Prawa Administracyjnego procesowego..., 
przy tym znamienna, że wypowiedzi te, często trafne, a na pewno głębokie, dotyczą najczęściej szczegółów, tzn. przede wszystkim różnego rodzaju skutków procesowych, jakie ta instytucja może wywoływać. Szczególne znaczenie ma tutaj refleksja, że zrzeczenie się odwołania może uniemożliwiać późniejsze wniesienie skargi do sądu administracyjnego, gdyż w jego efekcie decyzja staje się ostateczna i prawomocna. Tamuje ono zatem konstytucyjne prawo do sądu. Są to analizy na pewno konieczne, jeśli się zważy, że zrzeczenie się odwołania figuruje w prawie pozytywnym, obowiązuje i doktryna, a także orzecznictwo sądowe ma obowiązek jej interpretacji ${ }^{19}$. W tym miejscu nie chodzi mi jednak o praktyczne znaczenie lub o konsekwencje instytucji zrzeczenia się odwołania administracyjnego de lege lata, ale o podstawową zasadę, jaka powinna rządzić w takiej sytuacji, będącą konsekwencją konstytucyjnego usytuowania administracyjnego toku instancji ${ }^{20}$.

Jestem zdania ${ }^{21}$ - i nie wycofam się z niego pomimo krytyki dotyczącej tego zapatrywania ${ }^{22}$ - że skoro odwołanie administracyjne jest publicznym, formalnym prawem podmiotowym ${ }^{23}$ (co do takiej jego kwalifikacji nikt nie ma wątpliwości), to jego zrzeczenie się nie jest możliwe. Cechą każdego prawa podmiotowego, w tym publicznego prawa podmiotowego, jest przecież to, że jest ono indywidualne i przypisane do danego podmiotu przez ustawę (także Konstytucję). Nie można go przekazać innemu podmiotowi i nie może być przedmiotem sukcesji. Te jego cechy nie wystarczają jednak dla wykluczenia możliwości zrzeczenia się tego prawa ${ }^{24}$. Kwestią przesądzającą jest to, że o istnieniu czyjegoś prawa podmiotowego stanowi ustawa, a nie wola podmiotu,

s. 93-96. Autorka pisze, że „wprowadzenie instytucji zrzeczenia się prawa odwołania (...) jest rozwiązaniem, które budzi podstawowe zastrzeżenia zwłaszcza z punktu widzenia obrony praw jednostki"; ibidem, s. 93.

19 Nota bene jest to niestety w ostatnim czasie pewna cecha prac prawniczych, zwłaszcza wielu doktoratów lub habilitacji z zakresu prawa administracyjnego, polegająca na tym, że nie analizuje się sedna, wartości, aksjologii i znaczenia danej instytucji albo powodów jej wprowadzenia, ale przystępuje się od razu do bezkrytycznego omawiania jej szczegółów, przyjmując, że ona istnieje, istnieć musi i że nie ma wątpliwości w kwestii tego istnienia. Taka metoda bardzo spłyca wywody naukowe i obniża jakość przedstawianych prac.

20 Prawo do wniesienia odwołania jest m.in. konstytucyjnym środkiem ochrony wolności i praw. W tym kontekście umożliwienie zrzekania się odwołania administracyjnego i pozwalanie na kształtowanie tego prawa podmiotom innym niż ustawodawca, jest niekonstytucyjne. Por. W. Jakimowicz, O normatywnej konstrukcji..., s. 47.

21 Por. J. Zimmermann, Aksjomaty postępowania administracyjnego, Warszawa 2017, s. 201 i n. oraz idem, Kilka refleksji o nowelizacji kodeksu postępowania administracyjnego, PiP 2017, z. 8, s. 15-16.

22 Por. brutalną krytykę Z. Kmieciaka, Oblicza nowelizacji kodeksu postępowania administracyjnego ( $w$ odpowiedzi prof. Janowu Zimmermannowi), PiP 2018, z. 2, s. 105, a także pogląd tego Autora o tym, że poszukiwanie w art. 176 ust. 1 Konstytucji publicznego prawa podmiotowego do zaskarżania orzeczeń administracyjnych "stanowi przejaw uproszczonego pojmowania prawa” - idem, Konstytucyjne podstawy prawa do odwołania w postępowaniu administracyjnym, ZNSA 2013, nr 2, s. 14. Nie sposób jednak zrozumieć, na czym to uproszczenie miałoby polegać.

23 W. Jakimowicz, O normatywnej konstrukcji..., s. 36. Na dalszych stronach cyt. artykułu Autor rozpatruje charakter zrzeczenia się prawa do wniesienia odwołania w kontekście celów publicznych praw podmiotowych.

${ }^{24}$ O szerszej dyskusji na temat ewentualności zrzekania się uprawnień administracyjnych pisze W. Jakimowicz; ibidem, s. 42 i n. 
który tym prawem ma się legitymować. W pewnym sensie jest to więc prawo „przymusowe", z którego można wprawdzie nie korzystać, ale nie można go samemu odrzucić. Podmiot obdarzony tym prawem z mocy ustawy nie może przecież z prawa tego rezygnować, gdyż tym samym sprzeniewierzyłby się tejże ustawie. Tę regułę uzupełnia w ramach prawa administracyjnego spostrzeżenie, że normy tego prawa są bezwzględnie obowiązujące, toteż wszelkie prawa lub uprawnienia nabyte na podstawie takich norm nie mogą być odrzucane przez ich adresatów. W tej sytuacji uważam, że nie ma usprawiedliwienia dla kroku ustawodawcy, wprowadzającego możliwość zrzeczenia się odwołania. Nie mogą tu mieć większego znaczenia inne zastrzeżenia, jakie można zgłosić do tej instytucji, mające w istocie charakter drugorzędny. Można bowiem zastanawiać się nad charakterem decyzji pierwszej instancji, wobec której strona zrzekła się odwołania i nad pytaniem, czy taka decyzja staje się rzeczywiście ostateczna lub nawet prawomocna. Można dyskutować nad charakterem prawnym i o skutkach „oświadczenia o zrzeczeniu się odwołania”25, a także nad celem tej instytucji, która miałaby powodować przyspieszenie postępowania o całe czternaście dni. Te kwestie stają się otwarte wtedy, gdy uzna się omawianą instytucję za słuszną. W przeciwnym jednak razie należy zauważyć, że jej zastosowanie nie może mieć charakteru ostatecznego i wiążącego, i że z deklaracji o zrzeczeniu się odwołania strona może się wycofać. Jej publiczne prawo podmiotowe wygasa bowiem dopiero po upływie czternastu dni od daty doręczenia decyzji ${ }^{26}$.

Mojej ogólnej tezy nie da się podważyć twierdzeniem, że dopuszczenie zrzeczenia się odwołania „nie godzi w konstytucyjne prawo podmiotowe do wniesienia odwołania, gdyż w żaden sposób nie niweczy istoty tego prawa. Nie znosi tego prawa, jak również nie stanowi jakiegokolwiek ograniczenia uniemożliwiającego skorzystanie z prawa do złożenia odwołania. Strona postępowania administracyjnego ma bowiem nadal zagwarantowaną ustawowo swobodę w kwestii odwołania się od decyzji wydanej w I instancji"27. Twierdzenie to, mające niewątpliwie za zadanie opartą na Konstytucji obronę prawa do zrzeczenia się odwołania, jest wyraźnie niekonsekwentne, i tym samym traci walor argumentu. Jego Autorka twierdzi bowiem sama, że zrzeczenie się

25 Wprowadzenie instytucji tego oświadczenia dodatkowo komplikuje całą sprawę choćby dlatego, że ustawa nie zastrzega żadnej formy dla takiego oświadczenia, a także nie określa ewentualnej możliwości wycofania się z takiego oświadczenia - por. M. Bąkowski, M. Bogusz, Postępowanie odwoławcze..., s. 33.

26 Już przed laty, komentując dawny art. 113 § 4 pkt 2 k.p.a., wprowadzający instytucję zrzeczenia się odwołania, nie kto inny, ale W. Dawidowicz stwierdzał, że „zrzeczenie się odwołania należy traktować jako każde inne złożone przez stronę w toku postępowania oświadczenie, które strona może w każdej chwili zmienić lub uzupełnić; oświadczenie takie wyraża jedynie istniejący w określonym momencie zamiar strony, natomiast nie może ograniczyć, a tym bardziej znieść (...) prawa do wniesienia odwołania [oraz] (...) wniesienie odwołania wbrew poprzedniemu zrzeczeniu się należy uważać za całkowicie dopuszczalne"; idem, Ogólne postępowanie administracyjne. Zarys systemu, Warszawa 1962, s. 216. Później, choć jeszcze przed wprowadzeniem tej spornej instytucji do k.p.a., jednoznacznie w tej kwestii wypowiedział się NSA w składzie siedmiu sędziów, stwierdzając, że oświadczenie o zrzeczeniu się prawa do wniesienia odwołania jest prawnie bezskuteczne - wyrok z dnia 11 stycznia 2010 r., I OPS 5/09. Por. też wyrok NSA z dnia 21 lutego 2006 r., I OSK 542/05, CBOSA.

27 M. Masternak-Kubiak, Zrzeczenie się prawa do odwołania..., s. 345. 
prawa podmiotowego wcale go nie niweczy, nie znosi a nawet nie ogranicza możliwości skorzystania z niego. Skoro tak, to zrzeczenie takie nie może być skuteczne - i o to właśnie chodzi w tej kwestii. Ustawodawca wprowadził więc instytucję bez znaczenia, gdyż jej adresat, nawet w przypadku skorzystania z możliwości zrzeczenia się odwołania, może w otwartym terminie odwołanie to złożyć właśnie dlatego, że posiada prawo podmiotowe.

Istotniejszych wątpliwości w kwestii przedstawionej tezy o wadliwości instytucji zrzeczenia się odwołania dostarcza analiza prawa innych i to wielu państw, w których zrzeczenie się odwołania jest od lat dopuszczalne a nawet jest uznawane za uprawnienie w sposób naturalny powiązane z odwołaniem administracyjnym ${ }^{28}$. Ten przegląd, dotyczący kilku ważnych krajów europejskich, mógłby być dla mnie ostrzeżeniem i spowodować zmianę wyrażonego poglądu. Tak jednak nie jest. Autorka tej analizy bowiem też wyraża pogląd, że „dobrowolna rezygnacja strony z prawa do zaskarżenia decyzji wydanej w konkretnej sprawie w pierwszej instancji (...) nie pozbawia strony publicznego prawa podmiotowego, ale przyznaje jej jedynie swobodę wyboru między możliwością uruchomienia toku instancji (...) a możnością szybszego uzyskania wiążącego ją rozstrzygnięcia"29. Swoboda wyboru jest odrębnym zagadnieniem, niemogącym naruszyć istoty prawa podmiotowego, a dotyczącym tylko korzystania z tego prawa. Autorka sama to zresztą słusznie przyznaje. Tak więc nawet stwierdzenie, że „zrzeczenie się odwołania jest instytucją trwale i mocno osadzoną w postępowaniu administracyjnym niektórych państw europejskich"30, nie może mnie zwieść z przyjętej drogi. Prawo podmiotowe do wniesienia odwołania jest i - nawet z wywodów moich adwersarzy wynika, że - ono obiektywnie istnieje. Można z niego korzystać lub nie. Dana ustawa procesowa może je obudowywać warunkami, terminami, obowiązkami składania oświadczeń, komplikacjami procesowymi, zawiłościami dotyczącymi charakteru decyzji, wobec której nastąpiło takie zrzeczenie się itd., jednak ono nie znika i trwa - można więc z niego skorzystać nawet po złożeniu wcześniejszego oświadczenia o jego zrzeczeniu się.

10. Inne wątpliwości, a wręcz protest ${ }^{31}$ powoduje druga instytucja dotycząca odwołania administracyjnego, wprowadzona cytowaną nowelizacją k.p.a. z 2017 r. Znowelizowana ustawa dopuszcza bowiem możliwość wprowadzania wyjątków od zasady dwuinstancyjności postępowania administracyjnego przez przepis szczególny. Tego rodzaju furtka w omawianej zasadzie jest sama w sobie niebezpieczna, a została ona niestety uzupełniona przez art. 15 samej ustawy nowelizującej. Otóż według ust. 1 tego artykułu, w terminie dwóch lat od dnia wejścia w życie ustawy (do końca maja 2019 r.) ministrowie mieli dokonać przeglądu aktów prawnych regulujących postępowania

28 A. Skóra: Zrzeczenie się odwołania w niektórych państwach europejskich. Uwagi na tle prawnoporównawczym [w:] Fenomen prawa administracyjnego. Księga Jubileuszowa Profesora Jana Zimmermanna, red. W. Jakimowicz, M. Krawczyk, I. Niżnik-Dobosz, Warszawa 209, s. 803 i n.

29 Ibidem, s. 804

30 Ibidem, s. 816

31 J.Zimmermann, Kilka refleksji o nowelizacji kodeksu postępowania administracyjnego, PiP 2017, z. 8, s. 17. 
administracyjne w zakresie dwuinstancyjności postępowań. Mieli to uczynić po to, żeby na tej podstawie inni ministrowie, a w ślad za nimi - Rada Ministrów przygotowała „zbiorczy raport dotyczący dwuinstancyjności postępowań administracyjnych". Ma on posłużyć do opracowania ustaw, które zlikwidują odwołanie w postępowaniach toczących się w danej dziedzinie. Z punktu widzenia wartości, jaka jest odwołanie administracyjne taka wizja jest szokująca. Okazuje się, że organy administracji publicznej mogą same określać, od jakich decyzji administracyjnych przez nie wydawanych służy lub nie służy odwołanie. Administracja publiczna może więc, poprzez swoje działania wewnętrzne, ustalać zakres, w jakim obywatele (strony) dysponują swoim publicznym prawem podmiotowym. W ten sposób zaprzepaszcza się jedną z zasad demokratycznego państwa prawnego i narusza się unormowania konstytucyjne. Daje się też do ręki samej administracji instrument blokujący zastrzeżenia, jakie obywatel może wyrażać w stosunku do działań tejże administracji. Ponadto posłużenie się w omawianej regulacji słowami „odwołanie jest konieczne” sugeruje, że ustawodawca traktuje ten środek prawny jako zło konieczne, a użycie zwrotu: „zasadne jest odstąpienie” sugeruje, że mogą istnieć przesłanki pozaprawne lub pozakonstytucyjne, mające być podstawą oceny zasadności odstąpienia od odwołania.

11. Jeszcze inne wątpliwości budzą wprowadzane instytucje, które faktycznie negują możliwość posługiwania się odwołaniem, wskazując wyraźnie tylko na środki nadzwyczajne lub surogat środka zwykłego w postaci zażalenia od zaświadczenia. Dotyczy to "milczącego załatwienia sprawy” (rozdział 8a, art. 122-122h k.p.a.), które, pełniąc rolę domniemanego aktu administracyjnego, wywołuje spory co do możliwości jego zaskarżenia w drodze odwołania ${ }^{32}$.

12. Przedstawiony obraz zapatrywań części polskiej doktryny prawa i postępowania administracyjnego, jak i obraz pociągnięć ustawodawczych dotyczących problematyki odwołania administracyjnego nie napawa optymizmem. Jest to jedno z tych zagadnień, w których uwydatnia się wyraźnie szkodliwe zjawisko instrumentalizacji prawa i odchodzenia od jego aksjologicznych pryncypiów. Część autorów, w tym niektórzy wybitni przedstawiciele doktryny prawa i postępowania administracyjnego nie zauważają, że ich twierdzenia prowadzą do znacznego obniżenia, jeśli nie do zanegowania rangi odwołania administracyjnego. Nie zauważają, że robić tego nie wolno w systemie, w którym sądownictwo administracyjne przybrało model kontrolny i nie zauważają, że w ten sposób zmierzają do drastycznego ograniczania praw obywatelskich. Co więcej, stawiają oni na jednym poziomie wartość, jaką w sobie niesie możliwość pełnego zaskarżenia decyzji administracyjnej i wartość oczywiście drugorzędną, jaką stanowi uproszczenie i przyspieszenie postępowania administracyjnego. Z kolei ustawodawca najwyraźniej dąży do ograniczenia odwołania administracyjnego, które od stulecia było zawsze instrumentem ochrony praw obywatela. Zaczyna tu dominować interes samej administracji publicznej, co jest sprzeczne z ideologią państwa

32 Por. M. Jaśkowska, Nowe instytucje w Kodeksie postępowania administracyjnego a ochrona uprawnień jednostki [w:] Tempora mutantur cum legibus. Księga Jubileuszowa z okazji 20-lecia Wydziału Prawa i Administracji UKSW, red. A. Tarwacka, Warszawa 2019, s. 28-29. 
prawnego, która zakłada komplementarność interesu publicznego i interesów indywidualnych, dając administracji publicznej prawo ich wyważania, ale nie dając możliwości ich ignorowania. Jest to jeszcze jedno z aktualnych zagrożeń konstytucyjnej zasady państwa prawnego i trudno się oprzeć wrażeniu, że wszystkie te kroki mają charakter polityczny. Trzeba wyrazić nadzieję, że doktryna prawa administracyjnego i orzecznictwo sądów administracyjnych nie dopuszczą do degradacji odwołania, będącego najbardziej demokratycznym środkiem prawnym w obrębie prawa administracyjnego. Nie dopuszczą do pozbawienia obywatela - jednostki, podstawowego instrumentu, przy pomocy którego może on bronić swoich praw i interesów podczas postępowania administracyjnego.

\section{Literatura}

Adamiak B., Konstytucyjna zasada dwuinstancyjności postępowania administracyjnego [w:] Pozycja samorządowych kolegiów odwoławczych w postępowaniu administracyjnym, red. C. Martysz, E. Matan, Kraków 2005.

Adamiak B., Weryfikacja rozstrzygnięć w toku instancji [w:] System Prawa Administracyjnego, t. 9, Prawo procesowe administracyjne, red. R. Hauser, Z. Niewiadomski, A. Wróbel, Warszawa 2010.

Adamiak B., Zasada dwuinstancyjności postępowania administracyjnego w świetle zmian struktury organizacyjnej organów administracji publicznej. Miejsce zasady dwuinstancyjności w systemie gwarancji praw jednostki [w:] Jednostka wobec działań administracji publicznej, red. E. Ura, E. Feret, S. Pieprzny, Rzeszów 2011.

Adamiak B. [w:] System Prawa Administracyjnego Procesowego, t. 2, Weryfikacja rozstrzygnięć w postępowaniu administracyjnym ogólnym, red. eadem, Warszawa 2019.

Bąkowski M., Bogusz M., Postępowanie odwoławcze w ogólnym postępowaniu administracyjnym, t. 1, red. M. Bogusz, Gdańsk 2019.

Chróścielewski W., Kasacyjny czy reformacyjny model administracyjnego postępowania odwoławCzego?, „Państwo i Prawo” 2015, z. 1.

Dawidowicz W., Ogólne postępowanie administracyjne. Zarys systemu, Warszawa 1962.

Dąbrowski P., Granice prawa do odwołania administracyjnego w świetle Konstytucji RP [w:] Samorządowe kolegia odwoławcze - przeszłość i przyszłość, red. K. Sieniawska, Kraków 2011.

Dąbrowski P., Niedewolutywność środka zaskarżenia w postępowaniu administracyjnym a motywy aktualnego ustawodawcy [w:] Jakość prawa administracyjnego, red. D.R. Kijowski, A. Suławko-Karetko, Warszawa 2012.

Iserzon E. [w:] idem, J. Starościak, Kodeks postępowania administracyjnego. Komentarz, teksty, wzory i formularze, Warszawa 1970.

Jakimowicz W., O normatywnej konstrukcji zrzeczenia się prawa do wniesienia odwołania od decyzji administracyjnej, ,Przegląd Prawa Publicznego" 2018, nr 9.

Jaśkowska M., Nowe instytucje w Kodeksie postępowania administracyjnego a ochrona uprawnień jednostki [w:] Tempora mutantur cum legibus. Księga Jubileuszowa z okazji 20-lecia Wydziału Prawa i Administracji UKSW, Warszawa 2019, s. 28-29.

Kmieciak Z., Odwołania w postępowaniu administracyjnym, Warszawa 2011.

Kmieciak Z., Konstytucyjne podstawy prawa do odwołania w postępowaniu administracyjnym, "Zeszyty Naukowe Sądownictwa Administracyjnego" 2013, nr 2. 
Kmieciak Z., Zarys teorii postępowania administracyjnego, Warszawa 2014.

Kmieciak Z., Oblicza nowelizacji kodeksu postępowania administracyjnego (w odpowiedzi prof. Janowi Zimmermannowi), „Państwo i Prawo” 2018, z. 2.

Masternak-Kubiak M., Zrzeczenie się prawa do odwołania w postępowaniu administracyjnym [w:] Jednostka wobec władczej ingerencji organów administracji publicznej. Księga Jubileuszowa dedykowana Profesor Barbarze Adamiak, red. J. Korczak, K. Sobieralski, Wrocław 2019.

Oleś M., Aksjologia administracyjnego toku instancji jako instrumentu ochrony podmiotu administrowanego w zetknięciu z jurysdykcyjnym działaniem organu administracji publicznej [w:] Aksjologia prawa administracyjnego, red. J. Zimmermann, Warszawa 2017.

Skóra A., Zrzeczenie się odwołania w niektórych państwach europejskich. Uwagi na tle prawnoporównawczym [w:] Fenomen prawa administracyjnego. Księga Jubileuszowa Profesora Jana Zimmermanna, red. W. Jakimowicz, M. Krawczyk, I. Niżnik-Dobosz, Warszawa 2009.

Wróbel A. [w:] idem, M. Jaśkowska, Kodeks postępowania administracyjnego. Komentarz, Kraków 2000.

Wyrzykowski M., Ziółkowski M., Konstytucyjny status proceduralny jednostki jako adresata działań organów administracji [w:] System Prawa Administracyjnego, red. R. Hauser, Z. Niewiadomski, A. Wróbel, t. 2, Konstytucyjne podstawy funkcjonowania administracji publicznej, Warszawa 2012.

Zimmermann J., Aksjomaty postępowania administracyjnego, Warszawa 2017.

Zimmermann J., Kilka refleksji o nowelizacji kodeksu postępowania administracyjnego, „Państwo i Prawo" 2017, z. 8.

\section{Streszczenie}

\section{Jan Zimmermann}

\section{Czy schyłek odwołania administracyjnego?}

Odwołanie w postępowaniu administracyjnym jest podstawowym środkiem prawnym i jednocześnie najważniejszym instrumentem chroniącym w tym postępowaniu prawa obywatelskie. Znaczenia i funkcji tej instytucji w demokratycznym państwie prawnym nie da się przecenić. W ostatnim czasie pojawiają się jednak niebezpieczne zapatrywania doktrynalne i kroki ustawodawcze, zmierzające do zmniejszenia roli tej instytucji. W artykule dokonano przeglądu i oceny tych niepokojących zjawisk. Kontrowersyjne poglądy doktryny polegają na jednostronnej interpretacji przepisów konstytucyjnych, na przyznawaniu wyłącznie znaczenia procesowego odwołaniu administracyjnemu, a także na porównywaniu administracyjnego toku instancji z działaniami sądów administracyjnych. Autor zauważa również błędne traktowanie w doktrynie odwołania jako swoistej przeszkody w realizacji zasady szybkości postępowania administracyjnego oraz niebezpieczne postulaty rezygnacji z dewolutywności odwołania i dawania przewagi kompetencjom kasacyjnym organu odwoławczego. W zakresie ustawodawczym odnotowuje on kontrowersje związane z nową instytucją zrzeczenia się odwołania, a także z unormowaniem umożliwiającym organom administracji publicznej rezygnację z odwołania w wybranych dziedzinach. Przeprowadzona analiza prowadzi do pesymistycznego wniosku wskazującego na wyraźną obecnie tendencję do deprecjonowania instytucji odwołania administracyjnego. Artykuł ostrzega przed tymi niebezpieczeństwami, godzącymi w prawa obywatelskie. 


\section{Summary}

\section{Jan Zimmermann}

\section{Will the administrative appeal decline?}

The appeal in administrative proceedings is the basic legal measure and at the same time the most important instrument protecting civil rights in this proceeding. The significance and functions of this institution in a democratic state of law cannot be overestimated. Recently, however, there are dangerous doctrinal views and legislative steps aimed at reducing the role of this institution. The article reviews and evaluates these disturbing phenomena. The controversial views of the doctrine concerns the unilateral interpretation of constitutional provisions, granting administrative appeal only procedural significance, as well as comparing the administrative course of instance with the actions of administrative courts. The author also points to the erroneous treatment of the appeal in the doctrine as a kind of an obstacle to the implementation of the principle of speed of administrative proceedings as well as dangerous postulates of resigning from the devolutive effect of the appeal and giving an advantage to the cassation competence of the appeal body. In regard to legislation, the author points to the controversy related to the new institution of the waiver of the appeal as well as the regulation enabling public administration bodies to resign from the appeal in selected areas. The analysis leads to a pessimistic conclusion indicating a current trend to depreciate the institution of administrative appeal. The article warns of these dangers that violate civil rights.

Słowa kluczowe: demokratyczne państwo prawne, tok instancji, środek prawny, odwołanie, dewolutywność, kasacyjność, zrzeczenie się odwołania

Keywords: democratic state ruled by law, instance procedure, legal remedy, appeal, devolutive effect, cassation, waiver of appeal 